McDowall, D. G., Ledingham, I. McA., Jacobson, I., and Norman, J. N. (1965). Anesthesiology, 26, 720 .

MacKenzie, G. J., Taylor, S. H., Flenley, D. C., McDonald, A. H., Staunton, H. P., and Donald, K. W. (1964). Lancet, 2, 825 .

McNicol, M. W., Kirby, B. J., Bhoola, K. D., Everest, M. E., Price, H. V., and Freedman, S. F. (1965). Brit. med. F., 2, 1270

Malmcrona, R., and Varnauskas, E. (1964). Acta med. scand., 175, 1. Murdoch, W. R., Kenmure, A. C. F., Hutton, I., and Cameron, A. J. V. (1968). In preparation.
Taylor, S. H., and Shillingford, J. P. (1959). Brit. Heart f., 21, 497. Thomas, M., Malmcrona, R., and Shillingford, J. (1965a). Circulation, 31, 811 .'

Thomas, M., Malmcrona, R., and Shillingford, J. (1965b). Brit. Heart 7., 27, 401 .

Valentine, P. A., Fluck, D. C., Mounsey, J. P. D., Reid, D., Shillingford, J. P., and Steiner, R. E.' (1966). Lancet, 2, 837.

Whalen, R. E., Saltzman, H. A., Holloway, D. H., McIntosh, H. D., Sieker, H.'O., and Brown, I. W., (1965). Amer. F. Cardiol., 15, 638.

\title{
Late Ventricular Dysrhythmias after Myocardial Infarction
}

\author{
F. H. N. SPRACKLEN, ${ }^{*}$ M.D., M.R.C.P.; E. M. M. BESTERMAN, ${ }^{*}$ M.A., M.D., F.R.C.P. \\ M. S. EVEREST,* M.B., M.R.C.P. ; J. W. LITCHFIELD,* B.M., F.R.C.P. ; M. PETRIE,* A.S.C.T.
}

Brit. med. 7., 1968, 4, 364-366

\begin{abstract}
Cummary : Serious ventricular dysrhythmias occurred in $\checkmark$ hospital after discharge from a coronary intensive care unit in 11 out of 142 patients with myocardial infarction. Previous rhythm changes, hypotension, and left ventricular failure were common findings; only one of these patients had an uneventful previous course. Four patients were resuscitated and left hospital; six were resuscitated but died at varying periods up to eight days after the event ; one patient could not be resuscitated. Recent coronary occlusion or further myocardial infarction was demonstrated in 7 of these 11 patients and presumably accounted for the dysrhythmia.
\end{abstract}

\section{Introduction}

Serious ventricular dysrhythmias may still occur after the acute phase of cardiac infarction has passed, and their cause remains undecided. These dysrhythmias could be due to persistent electrical instability of the heart muscle, or be the result of a further ischaemic episode. As this problem has obvious therapeutic consequences, an analysis was made of ventricular dysrhythmias both in and after discharge from the Coronary Care Unit of St. Mary's Hospital.

Electrocardiographic monitoring of patients has shown an incidence of $70-90 \%$ of cardiac dysrhythmias in the first 48 hours after acute myocardial infarction (Julian et al., 1964 ; Killip and Kimball, 1967 ; MacMillan et al., 1967). The increasing use of coronary care units has facilitated the recognition and correction of otherwise fatal dysrhythmias and also their prevention (Spracklen et al., 1968). In the absence of recurring or continuing complications it is unusual for patients to be kept in one of these units for more than six days (Day, 1965 ; Yu et al., 1965 ; MacMillan et al., 1967 ; Restieaux et al., 1967 ; Pentecost and Mayne, 1968 ; Thomas et al., 1968).

\section{Patients and Results}

A total of 216 patients with suspected myocardial infarction were admitted to the coronary intensive care unit between October 1966 and April 1968. Of these, 163 were subsequently shown by electrocardiographic and enzyme studies to have suffered a myocardial infarction. In the absence of significant ventricular dysrhythmias, hypotension, or cardiac failure, patients were transferred to a general ward after five days. Ventricular tachycardia occurred in 11 patients and cardiac

\footnotetext{
* Department of Cardiology, St. Mary's Hospital, London W.2.
}

arrests due to ventricular fibrillation or asystole in $27(16.6 \%)$ while in the coronary unit. Of these 27 patients, 8 could not be resuscitated, 13 were resuscitated but died later in the unit, and 6 were resuscitated successfully and discharged from the unit and the hospital. Resuscitation in this early phase was most successful in patients with a ventricular dysrhythmia occurring within 24 hours of the onset of infarction: four out of nine such cases survived to leave hospital. A total of 142 patients were discharged from the unit in a stable rhythm. Subsequent "late" cardiac arrests occurred in nine of these patients $(6.3 \%)$ while they were still in hospital. This was caused by ventricular fibrillation in eight and by asystole in one. Ventricular tachycardia occurred in a further two patients. These 11 patients were readmitted to the unit and form the basis of the present study.

\section{Readmissions to Coronary Unit}

Relevant details concerning these 11 patients are presented in the accompanying Table. The time of the so-called "late" dysrhythmias varied from 7 to 64 days after initial admission to the coronary unit. It is notable that in only one instance was the patient's previous stay in the unit entirely uneventful. Of these 11 patients the dysrhythmia was precipitated by a pulmonary embolus in one, and in seven there was subsequent evidence of a further ischaemic episode. Of the latter patients necropsy demonstrated the presence of a recent coronary occlusion by a fresh thrombus in three. In four surviving patients there was electrocardiographic and enzyme evidence of further myocardial infarction. In three patients the cause of the terminal dysrhythmia remains undecided. Enzymes were increased in all three, but this by itself may have been due to repeated attempts at resuscitation. Thus in three patients persistent electrical instability is a possible but unproved cause of the ventricular dysrhythmia, whereas in the majority it would appear that a further ischaemic episode was responsible. In only one patient (Case 8 ) was the dysrhythmia preceded by cardiac pain. Only 2 of these 11 patients were on anticoagulant drugs at the time of the dysrhythmia. Of the 131 patients who left the unit and did not have further complications during the remainder of their hospital stay 34 were on anticoagulant therapy. There were no other late hospital deaths following myocardial infarction in this series.

Non-esterified fatty acid estimations had been determined on 18 occasions in six of these "late dysrhythmic" patients during the first five days of their initial admission to the coronary unit. The first blood sample, however, was usually obtained more than 12 hours after onset of the patient's symptoms. Thus 
Details of Cases

\begin{tabular}{|c|c|c|c|c|c|c|c|c|c|c|}
\hline \multirow{2}{*}{$\begin{array}{l}\text { Case } \\
\text { No. }\end{array}$} & \multirow{2}{*}{\multicolumn{2}{|c|}{$\begin{array}{l}\text { Age } \\
\text { and Sex }\end{array}$}} & \multirow{2}{*}{ Rhythm } & \multirow{2}{*}{$\begin{array}{c}\text { Days after } \\
\text { First } \\
\text { Admission } \\
\text { to Unit } \\
\end{array}$} & \multicolumn{2}{|c|}{$\begin{array}{l}\text { Evidence for Further } \\
\text { Myocardial Infarction }\end{array}$} & \multirow{2}{*}{$\begin{array}{l}\text { Initial Course in } \\
\text { Coronary Care Unit }\end{array}$} & \multirow{2}{*}{$\begin{array}{c}\text { Course after } \\
\text { Late Dysrhythmia }\end{array}$} & \multirow{2}{*}{$\begin{array}{c}\text { Cardiac Drug Therapy } \\
\text { Preceding Late } \\
\text { Dysrhythmia }\end{array}$} & \multirow{2}{*}{ Necropsy } \\
\hline & & & & & E.C.G. & Enzymes & & & & \\
\hline 1 & 69 & $\mathbf{M}$ & $\begin{array}{l}\text { Ventricular } \\
\text { fibrillation }\end{array}$ & 22 & No & Yes & Atrial fibrillation & Recurrent ventricular & $\begin{array}{l}\text { Warfarin, digoxin, } \\
\text { frusemide, Slow-K }\end{array}$ & Not done \\
\hline 2 & 36 & $M$ & $\begin{array}{r}\text { Ventricular } \\
\text { fibrillation }\end{array}$ & 64 & \multicolumn{2}{|c|}{ Data not available } & $\begin{array}{l}\text { Frequent ventricular } \\
\text { ectopic beats. Partial } \\
\text { A-V block. Left } \\
\text { ventricular failure }\end{array}$ & $\begin{array}{l}\text { Recurrent ventricular } \\
\text { fibrillation. Died on } \\
2 \text { nd day }\end{array}$ & $\begin{array}{l}\text { Warfarin, Cedilanid, } \\
\text { ethracrynic acid, } \\
\text { Slow-K }\end{array}$ & $\begin{array}{l}\text { Widespread coronary } \\
\text { artery disease. No } \\
\text { recent infarction }\end{array}$ \\
\hline 3 & 35 & $M$ & $\begin{array}{l}\text { Ventricular } \\
\text { fibrillation }\end{array}$ & 20 & \multicolumn{2}{|c|}{ Data not available } & $\begin{array}{l}\text { Ventricular fibrillation. } \\
\text { Hypotension }\end{array}$ & Died on 3rd day & $\begin{array}{l}\text { Digoxin, frusemide, } \\
\text { Slow-K }\end{array}$ & $\begin{array}{l}\text { Recent myocardial } \\
\text { infarction }\end{array}$ \\
\hline 4 & 68 & $M$ & $\begin{array}{c}\text { Ventricular } \\
\text { fibrillation }\end{array}$ & 9 & Yes & Yes & $\begin{array}{l}\text { Shock. Left ventricular } \\
\text { failure. Diabetes. Short } \\
\text { period of atrial flutter }\end{array}$ & Recovered & $\begin{array}{l}\text { Digoxin, frusemide, } \\
\text { Slow-K, insulin }\end{array}$ & \\
\hline 5 & 68 & $M$ & $\begin{array}{r}\text { Ventricular } \\
\text { fibrillation }\end{array}$ & 13 & Yes & Yes & $\begin{array}{l}\text { Ventricular fibrillation. } \\
\text { Mild left ventricular } \\
\text { failure. Aspiration } \\
\text { pneumonia }\end{array}$ & Recovered & Frusemide, Slow-K & \\
\hline 6 & +4 & M & $\begin{array}{l}\text { Ventricular } \\
\text { fibrillation }\end{array}$ & 15 & Yes & Yes & $\begin{array}{l}\text { Left ventricular failure. } \\
\text { Syphilis (treated) }\end{array}$ & Recovered & $\begin{array}{l}\text { Digoxin, frusemide, } \\
\text { Slow-K }\end{array}$ & \\
\hline 7 & 60 & $M$ & $\begin{array}{c}\text { Ventricular } \\
\text { tachycardia }\end{array}$ & 16 & Yes & Yes & Uneventful & Recovered & $\begin{array}{l}\text { Digoxin, frusemide, } \\
\text { Slow-K }\end{array}$ & \\
\hline 8 & 59 & $M$ & $\begin{array}{l}\text { Ventricular } \\
\text { asystole }\end{array}$ & 7 & No & Yes & $\begin{array}{l}\text { Frequent ventricular ecto- } \\
\text { pic beats. Pericardial } \\
\text { friction rub. Hyperten- } \\
\text { sion }\end{array}$ & Died same day & Frusemide, Slow-K & Not done \\
\hline 9 & 67 & $\mathrm{~F}$ & $\begin{array}{l}\text { Ventricular } \\
\text { fibrillation }\end{array}$ & 21 & & & $\begin{array}{l}\text { Atrial fibrillation. Left } \\
\text { ventricular failure. } \\
\text { Shock. Asystolic arrest } \\
\text { on 2nd day. Haema- } \\
\text { temesis and melaena }\end{array}$ & Died immediately & $\begin{array}{l}\text { Digoxin, frusemide, } \\
\text { Slow-K }\end{array}$ & $\begin{array}{l}\text { Recent coronary } \\
\text { thrombosis and } \\
\text { pulmonary } \\
\text { infarction }\end{array}$ \\
\hline 10 & $t$ & $\mathrm{~F}$ & $\begin{array}{c}\text { Ventricular } \\
\text { tachycardia }\end{array}$ & 13 & No & Yes & $\begin{array}{l}\text { Postoperative. Supra- } \\
\text { ventricular tachycardia. } \\
\text { Hypotension. Mild left } \\
\text { ventricular failure }\end{array}$ & $\begin{array}{l}\text { Pulmonary infarction. } \\
\text { Fractured ribs. Kleb- } \\
\text { siella pulmonary infec- } \\
\text { tion and septicaemia. }\end{array}$ & $\begin{array}{l}\text { Digoxin, frusemide, } \\
\text { Slow-K }\end{array}$ & Not done \\
\hline 11 & 54 & $M$ & $\begin{array}{l}\text { Ventricular } \\
\text { fibrillation }\end{array}$ & 10 & No & No & $\begin{array}{l}\text { Extension of myocardial } \\
\text { infarct on 5th day. } \\
\text { Triple rhythm. } \\
\text { Carcinoma of rectum }\end{array}$ & $\begin{array}{l}\text { Died on 6th day } \\
\text { Died on 8th day }\end{array}$ & Nil & $\begin{array}{l}\text { Recent coronary } \\
\text { thrombosis }\end{array}$ \\
\hline
\end{tabular}

these results cannot be compared with those of Oliver et al. (1968). The method used for estimation was that of Antonis (1965). The mean value for non-esterified fatty acid in these patients was $289 \mu \mathrm{Eq} /$ litre (S.E. 29). Fifty blood samples taken from 18 other patients with an uncomplicated course following the onset of infarction were similarly analysed. The mean value for non-esterified fatty acid in the latter patients was $250 \mu \mathrm{Eq} /$ l. (S.E. 17). Statistical analysis of these two sets of values showed no significant difference.

\section{Discussion}

Experimental evidence has shown that the risk of ventricular tachycardia is significant only within seven days of myocardial infarction (Wolff et al., 1968). Clinically, monitoring has shown that the greatest incidence of ventricular dysrhythmia occurs within the first 48 hours of myocardial infarction (Lown et al., 1967 ; Oliver et al., 1967 ; Pantridge and Geddes, 1967). For administrative reasons it is necessary to limit the length of the patient's stay in an intensive care unit, and this is usually under six days provided the patient is not suffering from any persistent complication of the initial infarction. The patient remains at risk, however, and ventricular fibrillation can occur at any time within the first four weeks of myocardial infarction (Restieaux et al., 1967); this has led some workers to continue to monitor patients after discharge from the coronary unit (Thomas et al., 1968). Our own experience of 11 instances of ventricular dysrhythmia in 142 patients discharged from the coronary unit reinforces these observations.

Pentecost and Mayne (1968), in a series of 317 patients with myocardial infarction, reported seven cases of delayed cardiac arrest. Six died, and necropsy in three showed evidence of recent infarction. Post-mortem examination was not carried out in the other three. In the one survivor there was electrocardiographic and enzyme evidence of an extension of the previous infarct. Like Lawrie et al. (1967), these authors therefore concluded that long-term monitoring of patients with myocardial infarction was unprofitable in terms of reducing mortality. In this respect our own experiences differed in that 10 out of 11 patients with a "late" ventricular dysrhythmia were resuscitated initially, and four survived to leave hospital. Simi- larly Restieaux et al. (1967) resuscitated 5 out of 10 patients who developed ventricular fibrillation between the 6 th and 24 th days after the onset of infarction. One of their survivors died seven days later.

Ventricular asystole has a poor prognosis whether it occurs early or late after a myocardial infarction. The reason is presumably because this rhythm change is usually associated with shock and cardiac failure, and is an indication of severe myocardial damage (Goble et al., 1966; Lawrie et al., 1967 ; Restieaux et al., 1967 ; Day, 1968). Thomas et al. (1968) advocated the use of a ward adjacent to the coronary unit to which patients can be transferred before being moved to a general ward. Eight of our 11 patients were in a ward adjacent to our coronary unit at the time of their late ventricular dysrhythmia. Four of these patients survived to leave hospital. It is difficult to draw firm conclusions from such a small group. It is possible, however, that the presence of trained staff and the ready availability of equipment for resuscitation might improve the prognosis of patients developing ventricular dysrhythmias in such wards.

In five of their seven patients Pentecost and Mayne (1968) drew attention to the presence of complications such as cardiac failure and dysrhythmias in the previous course. Lawrie et al. (1967) stated that if a patient is likely to develop serious dysrhythmias at a later stage some indication of this will occur within the first 48 hours. Our experience has been similar in that 7 of our 11 patients had major complications initially (ventricular fibrillation, shock, left ventricular failure), three had less severe cardiac complications, and in only one patient was the initial course entirely uneventful.

With regard to long-term prognosis in myocardial infarction, Denborough et al. (1968) showed that major dysrhythmias occurring in hospital are associated with an increased incidence of sudden death after discharge from hospital. Geddes et al. (1967), on the other hand, reported that the long-term prognosis after a small myocardial infarct is uninfluenced by the occurrence of ventricular fibrillation during the patient's initial stay in hospital.

Pentecost and Mayne (1968) suggested that the late occurrence of cardiac arrest after myocardial infarction is usually due to fresh infarction. Our findings in seven patients strongly 
support this suggestion. In three cases enzyme changes alone were considered insufficient evidence for further infarction. Electrical instability of the heart as a definite cause of late ventricular dysrhythmias can only be incriminated with certainty in patients in whom an irritable myocardium persists after the acute phase. Denborough et al. (1968) postulated an increased sensitivity to catecholamines as a cause of late ventricular dysrhythmias. Bjerkelund (1957) suggested that a sudden disturbance of electrical conduction of the heart might lead to ventricular fibrillation or asystole. Various other precipitating factors have also been implicated, including inadequate rest, acidosis, hypoxia, excessive diuresis leading to hypokalaemia, digitalis therapy, and anaesthetic agents (Robinson et al., 1964 ; Restieaux et al., 1967 ; Siddons and Sowton, 1967). Oliver et al. (1968) showed a relationship between the level of free fatty acids in the serum and the incidence of early and late ventricular dysrhythmias. These authors, however, are undecided whether this relationship results from increased catecholamine activity or whether it is directly due to an increase in myocardial oxygen consumption caused by the utilization of free fatty acids.

Late ventricular dysrhythmias after myocardial infarction are particularly apt to occur in patients whose initial course is complicated by left ventricular failure, hypotension, or dysrhythmias. These late dysrhythmias are usually not heralded by a further episode of cardiac pain. Such "high risk" patients should be transferred to a ward adjacent to the coronary care unit before being moved to a more remote general ward. There is no evidence that anticoagulant drugs at present in use can reduce the incidence of further coronary occlusion or of late sudden death after myocardial infarction (Bjerkelund, 1957 ; Aspenström and Korsan-Bengsten, 1964 ; Denborough et al., 1968).

If the finding of further infarction or of fresh coronary occlusion in our small series is significant, there should then be a definite indication for the use of an effective antithrombotic agent in these patients. Electrical instability of the type that might benefit from prolonged use of antiarrhythmic agents is suggested by recurrent ventricular tachycardia or fibrillation in the acute phase of the infarction, or by the occurrence of multiple ventricular ectopic beats, especially of the $R$ on $T$ type
(Smirk and Palmer, 1960). Increasing sinus bradycardia, complete heart block, and a previous cardiac arrest are warnings of possible asystole, usually unsalvable (Meltzer and Kitchell, 1966 ; Lawrie et al., 1967). The patients for whom one has obviously the greatest responsibility are those with hearts that are "too good to die" (Beck and Leighninger, 1960). This has been shown in our small series to be a factor as worthy of attention in late cardiac arrests as in the early ones.

\section{REFERENCES}

Antonis, A. (1965). F. Lipid Res., 6, 307.

Aspenström, G., and Korsan-Bengsten, K. (1964). Acta med. scand., 176, 563.

eck, C. S., and Leighninger, D. S. (1960). F. Amer. med. Ass., 174, 133.

Bjerkelund, C. J. (1957). Acta med. scand., Suppl. No. 330.

Day, H. W. (1965). Amer. F. Cardiol., 15, 51.

Day, H. W. (1968). Amer. F. Cardiol., 21, 252.

Denborough, M. A., Lovell, R. R. H., Nestel, P. J., and Goble, A. J. (1968). Lancet, 1, 386.

Geddes, J. S., Adgey, A. A. J., and Pantridge, J. F. (1967). Lancet, 2, 273. Goble, A. J., Sloman, G., and Robinson, J. S. (1966). Brit. med. F., 1,

Julian, D. G., Valentine, P. A., and Miller, G. G. (1964). Amer. F. Med., 37, 915.

Killip, T., and Kimball, J. T. (1967). Amer. F. Cardiol., 20, 457.

Lawrie, D M., et al. (1967). Lancet, 2, 109.

Lown, B., Vassaux, C., Hood, W. B., Fakhro, A. M., Kaplinsky, E., and Roberge, G. (1967). Amer. f. Cardiol., 20, 494 .

MacMillan, R. L., Brown, K. W. G., Peckham, G. B., Kahn, O., Hutchison, D. B., and Paton, M. (1967). Amer. F. Cardiol., 20, 451 . Meltzer, L. E., and Kitchell, J. B. (1966). Progr. cardiovasc. Dis., 9, 50. Oliver, M. F., Julian, D. G., and Donald, K. W. (1967). Amer. F. Cardiol., 20, 465.

Oliver, M. F., Kurien, V. A., and Greenwood, T. W. (1968). Lancet, 1, 710.

Pantridge, J. F., and Geddes, J. S. (1967). Lancet, 2, 271.
Pentecost, B. L., and Mayne, N. M. C. (1968). Brit. med. F., 1, 830.

Restieaux, N., et al. (1967). Lancet, 1, 1285.

Robinson, J, S., Sloman, G., and McRae, C. (1964). Med. F. Aust., 1, 427 .

Siddons, H., and Sowton, E. (1967). Cardiac Pacemakers. Springfield,

Illinois.

Spracklen, F. H. N., Kimerling, J. J., Besterman, E. M. M., and Litchfield, J. W. (1968). Brit. med. F., 1, 89.

Thomas, M., Jewitt, D. E., and Shillingford, J. P. (1968). Brit. med. F., 1, 787 .

Wolff, G. A., Veith, F., and Lown, B. (1968). Cardiovasc. Res., 2, 111.

Wolf, G. A., Veith, F., and Lown, B. (1968). Cardiovasc. Res., 2, 111.
Yu, P. N., Fox, S. M., Imboden, C. A., and Killip, T. (1965). Mod. Conc. cardiovasc. Dis., 34, 23.

\title{
Dipyridamole : a Controlled Trial of its Effect in Acute Myocardial Infarction
}

\author{
A. E. GENT,* M.B., M.R.C.P. ; C. G. D. BROOK,* $\neq$ M.B., M.R.C.P.; T. H. FOLEY, † M.B., B.SC., M.R.C.P. \\ T. N. MILLER, *§ B.M., M.R.C.P.
}

Brit. med. $7 ., 1968,4,366-368$

\begin{abstract}
Summary : A controlled trial of oral dipyridamole in 103 patients with acute myocardial infarction showed no difference in the number of complications or deaths in either the control or the treated groups. It is concluded that dipyridamole has no benefit in acute myocardial infarction.
\end{abstract}

\section{Introduction}

The pyrimidopyrimidine derivative, dipyridamole (Persantin), has been shown in animal experiments to inhibit thrombus

* Medical Registrar, St. Thomas's Hospital, London S.E.1.

t Lecturer in Medicine, St. Thomas's Hospital, London S.E.1.

$¥$ House-physician, Hospital for Sick Children, Great Ormond Street, London W.C.1.

$\checkmark$ Senior Medical Registrar, Westminster Hospital, London S.W.1. formation in injured vessels and to increase the collateral circulation around an ischaemic area in the myocardium (Fam and McGregor, 1964 ; Emmons et al., 1965a ; Rees and Redding, 1967). The drug has been the subject of a number of clinical trials to assess its effect in angina, but its effect in acute myocardial infarction has not been evaluated. It is the purpose of this trial to determine the influence of treatment with dipyridamole on mortality and complications in the four weeks following acute myocardial infarction.

\section{Patients and Miethods}

Patients admitted to the trial received dipyridamole or placebo tablets, and the selection was made at random. Eleven patients, six in the placebo group and five in the treatment 